\title{
The Kallikrein-Kinin System in Bartter's Syndrome and Its Response to Prostaglandin Synthetase Inhibition
}

\author{
Joseph M. Vinci, John R. Gill, Jr., Robert E. Bowden, John J. Pisano, \\ Joseph L. Izzo, JR., NAZAM RADFAR, AdDISON A. TAYLOR, \\ Randall M. Zusman, Frederic C. BartTer, and Harry R. Keiser, \\ Hypertension-Endocrine Branch, National Heart, Lung, and Blood \\ Institute, National Institutes of Health, Bethesda, Maryland 20014
}

A B S T RACT The kallikrein-kinin system was characterized in seven patients with Bartter's syndrome on constant metabolic regimens before, during, and after treatment with prostaglandin synthetase inhibitors. Patients with Bartter's syndrome had high values for plasma bradykinin, plasma renin activity (PRA), urinary kallikrein, urinary immunoreactive prostaglandin E excretion, and urinary aldosterone; urinary kinins were subnormal and plasma prekallikrein was normal. Treatment with indomethacin or ibuprofen which decreased urinary immunoreactive prostaglandin $\mathrm{E}$ excretion by $67 \%$, decreased mean PRA (patients recumbent) from $17.3 \pm 5.3$ (S.E.M.) $\mathrm{ng} / \mathrm{ml}$ per $\mathrm{h}$ to $3.3 \pm 1.1 \mathrm{ng} / \mathrm{ml}$ per $\mathrm{h}$, mean plasma bradykinin (patients recumbent) from $15.4 \pm 4.4 \mathrm{ng} / \mathrm{ml}$ to $3.9 \pm 0.9 \mathrm{ng} / \mathrm{ml}$, mean urinary kallikrein excretion from $24.8 \pm 3.2$ tosyl-arginine-methyl ester units (TU)/ day to $12.4 \pm 2.0 \mathrm{TU} /$ day, but increased mean urinary kinin excretion from $3.8 \pm 1.3 \mu \mathrm{g} /$ day to $8.5 \pm 2.5 \mu \mathrm{g} / \mathrm{day}$. Plasma prekallikrein remained unchanged at 1.4 $\mathrm{TU} / \mathrm{ml}$. Thus, with prostaglandin synthetase inhibition, values for urinary kallikrein and kinin and plasma bradykinin returned to normal pari passu with changes in PRA, in aldosterone, and in prostaglandin E. The

A portion of this work was presented at the 33rd Annual Meeting of the American Federation for Clinical Research, April 1976, Atlantic City, N. J. and published in abstract form. 1976. Clin. Res. 24: 414A. (Abstr.)

Dr. Vinci's present address is Johns Hopkins Hospital, Division of Cardiology, 530 Blalock Building, Baltimore, Md. 21205. Dr. Bowden's present address is Stanford University School of Medicine, Division of Cardiology, Stanford, Calif. 94305. Dr. Radfar's present address is Mercy Hospital of Pittsburgh, Department of Pediatrics, Pittsburgh, Pa. 15219. Dr. Taylor's present address is Baylor College of Medicine, Department of Medicine, Houston, Tex. 77030. Dr. Zusman's present address is Massachusetts General Hospital Medical Services, Boston, Mass. 02114.

Received for publication 18 March 1977 and in revised form 13 February 1.978. results suggest that, in Bartter's syndrome, prostaglandins mediate the low urinary kinins and the high plasma bradykinin, and that urinary kallikrein, which is aldosterone dependent, does not control kinin excretion. The high plasma bradykinin may be a cause of the pressor hyporesponsiveness to angiotensin II which characterizes the syndrome.

\section{INTRODUCTION}

Bartter's syndrome is characterized by hypokalemic alkalosis, hyperreninemia, hyperaldosteronism, and juxtaglomerular cell hyperplasia (1). Patients with this syndrome have normal blood pressure, despite their hyperreninemia, and aldosteronism; their pressor response to intravenously administered angiotensin II or norepinephrine is subnormal $(1,2)$. Volume expansion with either saline or albumin does not change their blood pressure and does not suppress plasma renin activity (PRA) ${ }^{1}$ and aldosterone to normal values (3). When their dietary sodium is restricted, they conserve sodium but continue to lose potassium (1).

In recent studies in patients with Bartter's syndrome, Verberckmoes et al. (4) have found hyperplasia of renomedullary cells and Gill and associates (5) have shown that urinary prostaglandin $\mathrm{E}$ is increased, presumably as a result of increased synthetic activity of the renomedullary cells. This group and others $(6,7)$ have shown that treatment with prostaglandin synthetase inhibitors corrects many of the metabolic and hormonal derangements in the syndrome.

Studies from several laboratories have indicated that the vasodilator kallikrein-kinin system has several

\footnotetext{
'Abbreviations used in this paper: $\mathrm{PGE}_{2}$, prostaglandin $\mathrm{E}_{2}$; PRA, plasma renin activity; TAMe, $\alpha-N$-tosyl-L-arginine[ $\left.{ }^{3} \mathrm{H}\right]$ methyl ester; TU, TAMe units; UiPGEV, urinary immunoreactive prostaglandin $\mathrm{E}$ excretion.
} 
interrelationships with the renin-angiotensin-aldosterone system and with prostaglandins. Bradykinin stimulates prostaglandin synthesis in blood vessels and in the kidney, probably by activating enzymes which make substrate available for prostaglandin synthetase $(8-11)$. The response of plasma bradykinin to postural change, sodium depletion, and saline infusion parallels temporally the response of PRA and of angiotensin II (12). Urinary kallikrein, which is derived from the kidney (13), is increased in conditions in which sodiumretaining steroids are present in excess (14-17), but neither plasma nor urinary kinins are affected by sodium-retaining steroids (17).

To study the interrelationships between these systems, we characterized the kallikrein-kinin system, renin-angiotensin-aldosterone system, and prostaglandins in seven patients with Bartter's syndrome before, during, and after prostaglandin synthetase inhibition.

\section{METHODS}

Clinical methods. Seven Caucasian women with Bartter's syndrome, ranging in age from 9 to $46 \mathrm{yr}(30 \pm 16$, mean $\pm \mathrm{SD}$ ), were studied. All patients were hypokalemic, hyperreninemic, and had juxtaglomerular cell hyperplasia on renal biopsy, vascular hyposensitivity to infusions of angiotensin II, and conserved sodium normally in response to a low sodium intake. All patients but one have always been normotensive. The one exception has occasionally had elevated systolic blood pressures in the range of 150-170 $\mathrm{mm} \mathrm{Hg}$, although the averages of her systolic and diastolic pressures are $137 / 76 \mathrm{~mm} \mathrm{Hg}$. Six patients were fed constant diets containing $9 \mathrm{meq} \mathrm{Na}$ and $42-90 \mathrm{mec} \mathrm{K}$ daily. The diets were supplemented with $\mathrm{NaCl}$ and $\mathrm{KCl}$ to yield a total intake of $109 \mathrm{meq} \mathrm{Na}$ and 250 to $270 \mathrm{meq} \mathrm{K}$ daily. One patient, aged $9 \mathrm{yr}$, received a total intake of $59 \mathrm{meq} \mathrm{Na}$ and 165 meq $\mathrm{K}$ daily. Fluid intake was constant and approximately $2,500 \mathrm{ml} /$ day throughout the study. After 4 days of control observations, a prostaglandin synthetase inhibitor was given. Indomethacin was administered to six patients for 7-9 days, followed by 4-7 days of posttreatment observations. The dose of indomethacin was $150 \mathrm{mg}$ /day except in two patients, one of whom was given only $112 \mathrm{mg} /$ day because of marked sodium retention; the second was given only $75 \mathrm{mg} /$ day because she was a 9 -yr-old girl who weighed only $17 \mathrm{~kg}$. One patient received ibuprofen, $1,600 \mathrm{mg} /$ day.

25 normal Caucasian women, ranging in age from 19 to 58 yr $(26 \pm 12$ is mean $\pm S D)$ were fed constant diets for $1 \mathrm{wk}$, containing 9 meq $\mathrm{Na}$ and $70 \mathrm{meq} \mathrm{K}$ daily. The diets were supplemented with $100 \mathrm{meg} \mathrm{NaCl}$ and $30 \mathrm{meg} \mathrm{KCl}$ daily. Control observations were made on the 5th, 6 th, and 7 th days. 18 of these normal subjects were studied for 1 additional wk after withdrawal of the supplemental $\mathrm{NaCl}$; six of these normal subjects were repleted and then given a 9-meq sodium diet with indomethacin, $150 \mathrm{mg} /$ day, given on days 5-7 of the diet. Comparisons were made between observations on days 5-7 of sodium depletion alone and sodium depletion plus indomethacin.

All subjects were hospitalized at the Clinical Center, National Institutes of Health, during the study. The protocols for these studies were approved by the Clinical Research Committee of the National Institutes of Health and all subjects gave informed consent in writing.
Biochemical methods. Urine was collected daily in 24-h periods and each voiding was equally divided into two polypropylene containers. One container had $20 \mathrm{ml} 6 \mathrm{~N}$ $\mathrm{HCl}$ and $2 \mathrm{ml}$ of a $0.1-\mathrm{mg} / \mathrm{ml}$ solution of pepstatin, ${ }^{2}$ in methanol, while the other container had no additives. Urine was refrigerated during collection and immediately divided into aliquots for measurement of sodium, potassium, creatinine, aldosterone, prostaglandin E, kallikrein, and kinins.

Sodium, potassium, and creatinine in blood and urine, and chloride and $\mathrm{CO}_{2}$ in blood, were determined by standard techniques as previously described (18). Venous blood for the estimation of PRA by radioimmunoassay (19), plasma bradykinin, and plasma prekallikrein, was taken between 8:00 a.m. and 9:00 a.m. when the patient had been recumbent overnight. Urinary aldosterone was determined by radioimmunoassay (20). PRA was assayed by Hazelton Laboratories, Inc., Vienna, Va., under a special contract. Urinary immunoreactive prostaglandin E-like material was determined by a radioimmunoassay as recently reported (5). This assay gives values that are 0.6- to 3.4-fold higher than those assayed by gas chromatography-mass spectroscopy in the basal state and from 1.25- to 13.7-fold higher with prostaglandin inhibition (5). The reason for this discrepancy is unknown but is probably due to the presence of a prostaglandin or its metabolite as the levels of immunoreactive prostaglandin $\mathrm{E}$ are reduced to a similar extent in either assay by treatment of these patients with prostaglandin synthesis inhibitors (5).

Urinary kallikrein. Aliquots of urine were stored under toluene at $4^{\circ} \mathrm{C}$. At the completion of each individual study, samples were assayed in duplicate by a modification (21) of the radiochemical esterolytic method of Beaven et al. (22). The esterolytic activity of urine filtered through Sephadex G-25 (fine) (Pharmacia Fine Chemicals, Inc., Piscataway, N. J.) was determined with purified $\alpha-N$-tosyl-L-arginine- $\left[{ }^{3} \mathrm{H}\right]-$ methyl-ester (TAMe) as the substrate. The major TAMe esterase in human urine at the $\mathrm{pH}$ of this assay is kallikrein (14); the specificity of this assay has been confirmed by bioassay (14). In this study, esterase activity was identified as kallikrein in four patients with Bartter's syndrome and in four normal subjects; antibodies to either human urinary kallikrein or human kininogen were covalently bound to agarose.$^{3}$ When $0.40 \mathrm{ml}$ of urine was applied to $25 \mu \mathrm{l}$ of agarose, covalently bound to kallikrein antibody, only $12.0 \pm 2.5 \%$ (mean \pm SEM) of the esterase activity in the urine of patients with Bartter's syndrome was eluted. Similarly, 10.0 $\pm 1.5 \%$ of the esterase activity of urine from the normal subjects was eluted from this column. In contrast, all esterase activity $(99.0 \pm 2.5 \%)$ was eluted from the column containing antibody to kininogen. Thus, as previously demonstrated by bioassay, the major TAMe esterase in human urine is kallikrein. Standard curves of esterase activity were constructed for each assay with a functionally pure human urinary kallikrein standard (22). ${ }^{3}$ Four concentrations of standard were used in triplicate and a standard curve was generated by computer by the method of least squares. Values were computed for this curve and expressed as TAMe units (TU) excreted per $24 \mathrm{~h}$. 1 esterase unit is defined as that amount of kallikrein which hydrolyzes 1 micromole of TAMe per minute at $\mathrm{pH} 8.0$ and $30^{\circ} \mathrm{C}$ in a titrametric assay (23). A standard

\footnotetext{
${ }^{2}$ Kindly supplied by Dr. Walter Troll, State University of New York at Stony Brook, Stony Brook, N. Y.

${ }^{3}$ Kindly supplied by Dr. Jack V. Pierce, Laboratory of Chemistry, National Heart, Lung, and Blood Institute, National Institutes of Health, Bethesda, Md.
} 
urine was run with each assay to serve as a quality control. In 28 assays it gave a kallikrein value of $1.18 \pm 0.15 \mathrm{TU} / \mathrm{ml}$ $($ mean $\pm S D)$. An assay was repeated if this value was exceeded by $2 \mathrm{SD}$, or if duplicate samples varied by more than $10 \%$.

Prekallikrein. Whole blood $(1.7 \mathrm{ml})$ was drawn into a plastic syringe, emptied into a plastic tube containing 0.3 $\mathrm{ml}$ of an acid-citrate-dextrose solution, and mixed immediately at room temperature (21). The tube was centrifuged at room temperature and 200- $\mu$ l aliquots of plasma were quickly frozen and stored in plastic tubes at $-20^{\circ} \mathrm{C}$. Prekallikrein was determined in duplicate by a radiochemical esterolytic assay (21) against the same kallikrein standard used in the assay for urinary kallikrein. Values are expressed as TU per milliliter plasma.

Plasma bradykinin collection and processing. Whole blood was collected and processed by a modification of the method of Talamo et al. (24) and Wintroub et al. (25). $9 \mathrm{ml}$ of blood was collected through a no. 19 gauge siliconized butterfly needle (Abbott Diagnostics, S. Pasadena, Calif.) into a polypropylene syringe containing $0.15 \mathrm{ml}$ of solution that was $0.15 \mathrm{M} \mathrm{NaCl}$ with $3.6 \mathrm{mg}$ disodium EDTA, $9 \mathrm{mg}$ polybrene (Aldrich Chemical Co., Milwaukee, Wis.), and 45 nCi bradykinin triacetate [2-prolyl-3,4 ${ }^{3} \mathrm{H}(N)$ ] (sp act, 50 $\mathrm{Ci} / \mathrm{mmol}$ ). (The latter was purified weekly over CM-Sephadex C-25 with $0.5 \mathrm{M}$ ammonium acetate at $\mathrm{pH} 6.7$ and stored at $-70^{\circ} \mathrm{C}$.) Blood was mixed well with this solution as it was drawn and was then emptied immediately into a 12-ml polypropylene tube equilibrated at $0^{\circ} \mathrm{C}$. Plasma was separated at $12,000 \mathrm{~g}$ for $10 \mathrm{~min}$ at $4^{\circ} \mathrm{C}$ with $90-100 \%$ recovery of $\left[{ }^{3} \mathrm{H}\right]$ bradykinin. Duplicate $2-\mathrm{ml}$ aliquots were placed into two polypropylene tubes and precipitated with TCA (24) with no additional loss of $\left[{ }^{3} \mathrm{H}\right]$ bradykinin. The supernate was diluted 10-fold with $3.5 \mathrm{mM}$ phosphate buffer, pH 8.0 , and placed over a $1.5 \times 6.5-\mathrm{cm}$ plastic column of QAE-Sephadex A-25 (Pharmacia Fine Chemicals, Inc.) equilibrated with $3.5 \mathrm{mM}$ phosphate buffer (25). The sample was then adjusted to $\mathrm{pH} 4.0$ and placed over a $0.7 \times 1.5-\mathrm{cm}$ IRC-50 (100-200 mesh) column equilibrated in $0.1 \mathrm{~N}$ acetic acid (23). The initial effluent was discarded as well as the subsequent $3-\mathrm{ml}$ wash with $0.1 \mathrm{~N}$ acetic acid. Bradykinin was then eluted with $5 \mathrm{ml} 9 \mathrm{~N}$ acetic acid into a siliconized glass tube and flash evaporated at $40^{\circ} \mathrm{C}$. The dried sample was reconstituted in $0.5 \mathrm{ml}$ buffer used in the radioimmunoassay $(0.2 \mathrm{M}$ Tris-acetate buffer, $\mathrm{pH} 6.4$, with $0.1 \mathrm{M}$ EDTA and $1 \mathrm{mg} / \mathrm{ml}$ lysozyme). A $0.1-\mathrm{ml}$ aliquot was used to determine the recovery of $\left[{ }^{3} \mathrm{H}\right]$ bradykinin after processing. Mean recovery for 49 samples was $59 \pm 9 \%$ (mean \pm SD). Processed samples were stored in 1.5-ml microtest tubes (Brinkmann Instruments, Inc., Westbury, N. Y.) at $-20^{\circ} \mathrm{C}$ before assay and were stable for at least 1 mo. Samples were assayed at the completion of each individual study.

Urine collection and processing for urinary kinins. Urine was collected in $6 \mathrm{~N} \mathrm{HCl}$ to destroy kininases and in pepstatin to inhibit uropepsin, a urinary enzyme that has been shown to generate methionyl-lysyl-bradykinin in urine at $\mathrm{pH} 1$ to 2 in vitro; urine, collected in pepstatin, does not contain methionyl-lysyl-bradykinin (26). Samples were stored at $-20^{\circ} \mathrm{C}$ and were measured at the completion of each individual study. Urinary kinins, lysyl-bradykinin and bradykinin (27), are stable for up to 1 yr under these conditions. Before assay, urine was thawed adjusted to $\mathrm{pH} 6.4$ and centrifuged at $12,000 \mathrm{~g}$ for $10 \mathrm{~min}$.

Bradykinin radioimmunoassay. Urinary kinins and plasma bradykinin were determined by the same radioimmunoassay. The antibody was kindly supplied by Dr. J. V. Pierce who prepared it by immunization of sheep with highly purified human plasma low molecular weight kininogen I (27) in which the kinin moiety is at the carboxy terminus. This antibody, which was directed primarily to the C-terminal bradykinin moiety, had the following features. (a) It had essentially the same reactivity with bradykinin as with lysyl-bradykinin (the two kinins found in vivo in human urine) and methionyl-lysyl-bradykinin over a 0.04 to 2.0 pmol range; thus, this antibody gives a measure of total urinary kinins. (b) Kinin fragments consisting of amino acid residues $1-4,1-6,1-7,4-7,3-7,2-7$ were undetectable at the 100 -pmol level, but $100 \mathrm{pmol}$ of fragment 1-8 gave the same displacement as $0.25 \mathrm{pmol}$ bradykinin. (c) Its binding by the bradykinin moiety in low molecular weight kininogen I was only $5 \%$ of that by the bradykinin released by a similar amount of low molecular weight kininogen I; it did not significantly bind to other forms of kininogen.

The weak binding of kininogen $I$, which comprises about $20 \%$ of the total plasma pool, is inconsequential, as samples are processed to contain virtually no kininogen. Also, the mean value for kinin in 10 urine samples assayed by bioassay with the guinea pig ileum $(19.7 \pm 2.7 \mu \mathrm{g} / \mathrm{day})$ was similar to that obtained by our radioimmunoassay $(20.9 \pm 2.4 \mu \mathrm{g} / \mathrm{day})$. Agreement between bioassay and radioimmunoassay was very good and showed a correlation coefficient $(r)$ of 0.86 $(P<0.001)$ for these few samples.

Tyrosine-8-bradykinin (New England Nuclear, Boston, Mass.) was iodinated monthly with ${ }^{125} \mathrm{I}$ by the chloramine-T method ${ }^{4}$ and stored at $-70^{\circ} \mathrm{C}$ in Tris buffer, pH 6.4, with 1 $\mathrm{mg} / \mathrm{ml}$ lysozyme. Bradykinin standard was kindly supplied by Sandoz Ltd., Basel, Switzerland. Its purity and concentration were confirmed by amino acid analysis and bioassay in this laboratory.

In the radioimmunoassay each tube contained a total volume of $0.7 \mathrm{ml}$ which consisted of $0.2 \mathrm{ml}{ }^{125} \mathrm{I}$-tryosine-8bradykinin (13,000 dpm), $0.30 \mathrm{ml}$ antibody (1:10,000 dilution), 0.05 or $0.1 \mathrm{ml} \mathrm{sample}$, and 0.10 or $0.15 \mathrm{ml} 0.2 \mathrm{M}$ Trisacetate buffer, $\mathrm{pH} 6.4$, with $0.01 \mathrm{M}$ EDTA and $1 \mathrm{mg} / \mathrm{ml} \mathrm{lyso-}$ zyme. After incubation overnight, free and bound bradykinin were separated with $0.45-\mu \mathrm{m}$ Millipore filters (Millipore Corp., Bedford, Mass.) and counted in scintillation fluid. A standard curve with values from 125 to $2,000 \mathrm{pg}$ was run with each assay and analyzed by computer program (28) along with duplicate unknown samples. In 20 assays, the antibody gave $35 \pm 5.4 \%$ (mean \pm SD) binding of ${ }^{125}$ I-tyrosine-8-bradykinin at a 1:10,000 dilution of antibody. The slope was $-0.99 \pm 0.09$ in a log-logit plot of dose of bradykinin vs. the fraction of ${ }^{125} \mathrm{I}$-tyrosine-8-bradykinin bound; $50 \%$ inhibition of binding for bradykinin occurred with $300 \pm 36 \mathrm{pg}$ and the computed minimal detectable dose (i.e., the smallest amount of bradykinin the assay can determine to be different from zero) was $12 \pm 8 \mathrm{pg} /$ sample volume ( 120 $\pm 8 \mathrm{pg} / \mathrm{ml}$ sample). In those 20 assays, as with all assays, three control urine samples were run, showing interassay variability of $7.6,9.2$, and $10 \%$. Any duplicate samples whose values differed by more than $15 \%$ were repeated, and any assay in which there was more than a 2-SD difference in the three quality control samples was repeated. Values for plasma bradykinin were derived by computer from the mean of samples processed in duplicate. Each processed sample was assayed in duplicate, and the values were corrected for recovery of $45 \mathrm{nCi}$ bradykinin triacetate which was added to each syringe before venipuncture.

Statistical methods. Values are reported as mean $\pm \mathrm{SEM}$ unless stated otherwise. Student's $t$ test for paired samples was used to determine statistical significance and $P=0.05$ was considered the upper limit of significance.

\footnotetext{
${ }^{4}$ Thomas, Richard J. Personal communication.
} 


\section{RESULTS}

\section{Metabolic effects of prostaglandin synthetase inhibition}

The plan of the study and the effects of prostaglandin synthetase inhibition on these patients are presented in Fig. 1. In the control period, mean serum potassium was $2.4 \pm 0.2 \mathrm{meq} / \mathrm{liter}$, (mean $\pm \mathrm{SEM}$ ), mean PRA (patients recumbent) was $17.3 \pm 5.3 \mathrm{ng} / \mathrm{ml}$ per h (16 normal recumbent subjects on 109 meq $\mathrm{Na}$ intake had a value of $1.4 \pm 0.2 \mathrm{ng} / \mathrm{ml}$ per $\mathrm{h}$ ) and mean urinary aldosterone was $12.0 \pm 5.1 \mu \mathrm{g} /$ day ( 19 normal subjects on 109 meq $\mathrm{Na}$ intake excreted $4.5 \pm 0.5 \mu \mathrm{g} / \mathrm{day}$.) Blood pressure with patients supine was $107 / 70 \pm 6 / 3$ $\mathrm{mm} \mathrm{Hg}$. In addition, as recently reported (5) mean urinary immunoreactive prostaglandin $\mathrm{E}$ excretion (UiPGEV) was elevated to $70 \pm 11 \mathrm{ng} / \mathrm{h}$ as compared to that of normal subjects, who excreted $29 \pm 5 \mathrm{ng} / \mathrm{h}$ when fed a diet with 109 meq Na/day.

During prostaglandin synthetase inhibition there was an abrupt reduction of UiPGEV to $48 \%$ of control $(P<0.005)$ on the first day, and UiPGEV remained at 33 to $38 \%$ of control throughout the treatment period. There was significant retention of $51 \mathrm{meq}$ sodium on the 1st $(P<0.005)$ and 45 meq sodium on the 2 nd $(P<0.02)$ days of therapy. There was an increase in weight of $0.9 \pm 0.2 \mathrm{~kg}$ on the 1st day $(P<0.005)$ and of $1.8 \pm 0.4 \mathrm{~kg}$ by the 5 th day. Simultaneous with this early sodium retention, there was significant retention of $87 \mathrm{meq}$ potassium on the 1st $(P<0.02)$ and 45 meq on the 2nd $(P<0.05)$ day. Mean serum potassium rose from $2.4 \pm 0.2 \mathrm{meq} / \mathrm{liter}$ to $3.2 \pm 0.3$ meq/liter on the first day $(P<0.02)$ and remained elevated throughout treatment at a level of about 3.0 $\pm 0.1 \mathrm{meq} /$ liter. Serum $\mathrm{CO}_{2}$ (not shown) fell, serum chloride rose, and serum sodium was unchanged during treatment. Mean creatinine clearance was significantly reduced $(P<0.05)$ only on the 1st 3 days of treatment by 23,15 , and $10 \%$, respectively. In addition to these effects of prostaglandin synthetase inhibition, there was an early reduction of mean PRA (patients recumbent) from a control value of $17.3 \pm 5.3 \mathrm{ng} / \mathrm{ml}$ per $\mathrm{h}$ to 8.1 $\pm 3.9 \mathrm{ng} / \mathrm{ml}$ per $\mathrm{h}(P<0.05)$ (mean of the 1 st and $2 \mathrm{nd}$ days of treatment), and to $3.3 \pm 1.1 \mathrm{ng} / \mathrm{ml}$ per $\mathrm{h}(P$ $<0.025)$ on the 6 th and 7 th days. The reduction in PRA was followed by a significant reduction in aldosterone excretion on the 4th through 7 th days of treatment. Blood pressure was not significantly changed.

When the prostaglandin synthetase inhibitor was stopped, there was a brisk return of prostaglandin $\mathrm{E}$ excretion to $77 \pm 9 \%$ and $108 \pm 11 \%$ of control on the lst and 2 nd days, respectively, and urinary sodium excretion on these 2 days was over twice that on the last day

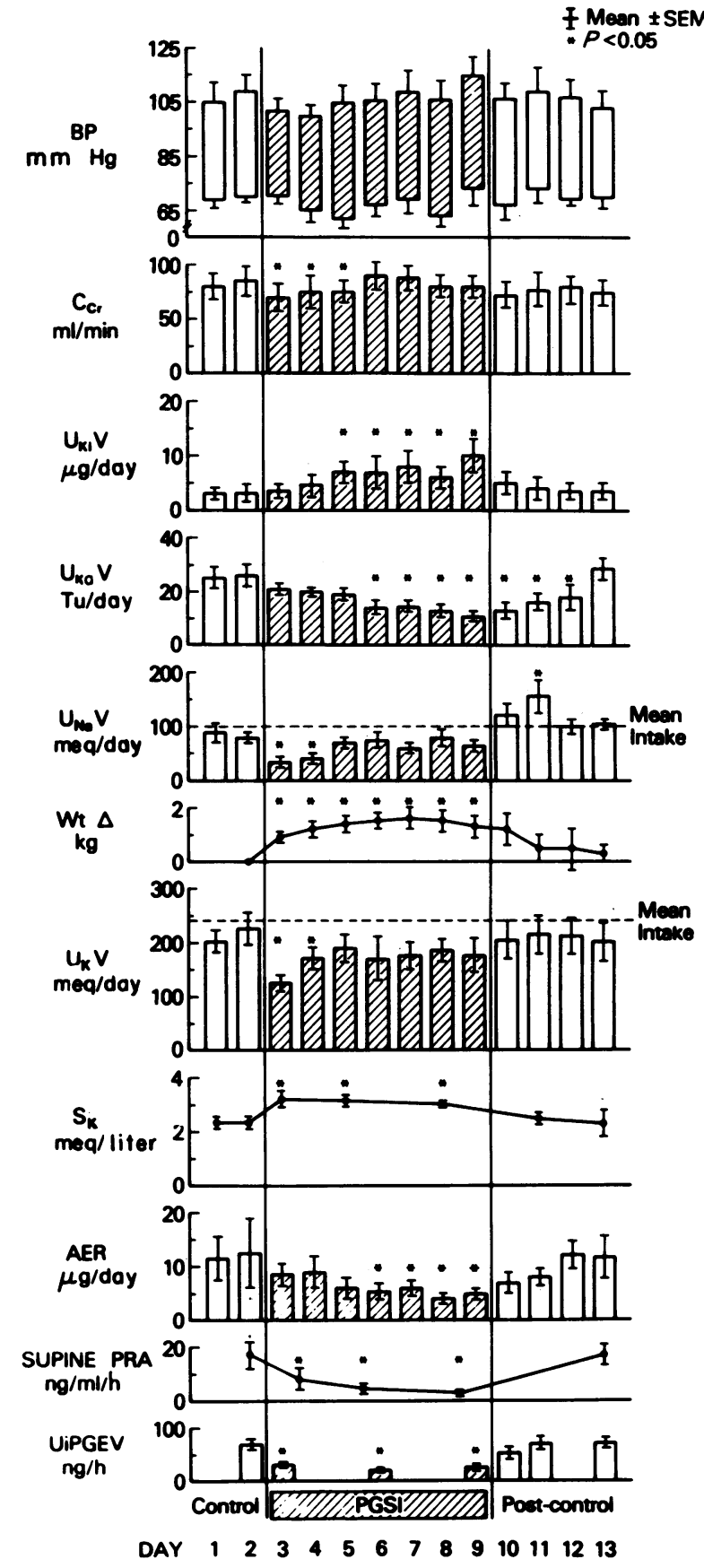

FIGURE 1 Effects of prostaglandin synthetase inhibition (PGSI) in seven patients with Bartter's syndrome on blood pressure $(\mathrm{BP})$, creatinine clearance $\left(\mathrm{C}_{\mathrm{Cr}}\right)$, kinin excretion $\left(U_{K_{1}} \mathrm{~V}\right)$, kallikrein excretion $\left(U_{K_{a}} V\right)$, urinary sodium excretion $\left(\mathrm{U}_{\mathrm{Na}} \mathrm{V}\right)$, weight change (Wt $\left.\Delta\right)$, urinary potassium excretion $\left(U_{K} V\right)$, serum potassium $\left(S_{K}\right)$, aldosterone excretion rate (AER), plasma renin activity (PRA), and urinary immunoreactive prostaglandin $\mathrm{E}$ excretion (UiPGEV). ${ }^{*}$ is $P<0.05$. When calculated as percentage change, AER is significantly different from control on days 6-9. 
of treatment $(P<0.05)$. With this natriuresis, weight, urinary potassium, serum potassium, aldosterone excretion, and PRA returned to control values. In Table I, the mean values in six normal subjects on days 5-7 of 9-meq/day sodium intake are compared to the mean values during indomethacin on days 5-7 of sodium depletion. During indomethacin, UiPGEV, PRA, and aldosterone excretion rate were significantly lower than during sodium depletion alone. Unlike patients with Bartter's syndrome, however, these subjects demonstrated no significant change in creatinine clearance during indomethacin. Although potassium excretion was significantly less $(P<0.05)$, as was aldosterone excretion, this was minor and had no effect on serum potassium.

\section{Kallikrein-kinin system, basal values}

Urinary kallikrein (Fig. 2A). Mean urinary kallikrein of 25 normal subjects with daily dietary intakes of $109 \mathrm{meq} \mathrm{Na}$ and $100 \mathrm{meq} \mathrm{K}$ was $8.2 \pm 7.4 \mathrm{TU} /$ day $($ mean $\pm 2 \mathrm{SD})$. These values are similar to those re-

TABLE I

Effect of Indomethacin on Sodium-Depleted Normals*

\begin{tabular}{|c|c|c|c|}
\hline & Control & Indomethacin & $P$ value \\
\hline & mean $\pm S E$ & mean $\pm S E$ & \\
\hline $\mathrm{C}_{\mathrm{Cr}}, m l / \min$ & $105 \pm 7$ & $110 \pm 9$ & NS \\
\hline $\mathrm{U}_{\mathrm{Ki}} \mathrm{V}, \mu \mathrm{g} / \mathrm{day}$ & $10.7 \pm 1.9$ & $11.1 \pm 1.0$ & NS \\
\hline $\mathrm{U}_{\mathrm{Ka}} \mathrm{V}, T U / d a y$ & $25.4 \pm 5.9$ & $15.8 \pm 4.0$ & $<0.02$ \\
\hline $\mathrm{U}_{\mathrm{Na}} \mathrm{V}$, meq/day & $4.3 \pm 1.1$ & $3.6 \pm 1.1$ & NS \\
\hline $\mathrm{Wt} \Delta, \mathrm{kg}$ & $-1.7 \pm 0.16$ & $-1.24 \pm 0.24$ & NS \\
\hline $\mathrm{U}_{\mathrm{K}} \mathrm{V}$, meq/day & $88 \pm 6$ & $77 \pm 7$ & $<0.05$ \\
\hline $\mathrm{S}_{\mathrm{K}}$, meq/liter & $3.9 \pm 0.1$ & $4.0 \pm 0.1$ & NS \\
\hline AER, $\mu g / d a y$ & $82.0 \pm 11.6$ & $60.5 \pm 5.1$ & $<0.05$ \\
\hline PRAR, $n g / m l / h$ & $4.3 \pm 0.5$ & $3.0 \pm 0.6$ & NS \\
\hline PRAU, $n g / m l / h$ & $9.9 \pm 1.4$ & $7.2 \pm 1.3$ & $<0.04$ \\
\hline PBKR, $n g / m l$ & $2.9 \pm 0.5$ & $2.7 \pm 0.6$ & NS \\
\hline $\mathrm{PBKU}, n g / m l$ & $4.2 \pm 0.5$ & $3.6 \pm 0.7$ & NS \\
\hline UiPGEV, $n g / h$ & $22.3 \pm 4.7$ & $13.4 \pm 2.8$ & $<0.01$ \\
\hline
\end{tabular}

Mean effects of indomethacin in sodium-depleted normal subjects. Six normal subjects were fed diets containing 9 meq/day sodium during two periods. Mean control observations were made on days 5-7 during the first period and again on days 5-7 in the second period when indomethacin, $150 \mathrm{mg} /$ day, was given.

* Abbreviations used in this table: $\mathrm{C}_{\mathrm{Cr}}$, creatinine clearance; $\mathrm{U}_{\mathrm{Ki}} \mathrm{V}$, urinary kinin excretion; $\mathrm{U}_{\mathrm{Ka}} \mathrm{V}$, urinary kallikrein excretion; $U_{\mathrm{Na}} \mathrm{V}$, urinary sodium excretion; $\mathrm{Wt} \Delta$, weight change; $U_{K} V$, urinary potassium excretion; $S_{K}$, serum potassium; AER, aldosterone excretion rate; PRA, plasma renin activity, subject recumbent $(R)$ and upright $(U)$; PBK, plasma bradykinin, subject recumbent $(R)$ and upright $(U)$; UiPGEV, urinary immunoreactive prostaglandin $\mathrm{E}$ excretion. ported previously by Margolius et al. (14) from this laboratory.

All patients with Bartter's syndrome excreted amounts above this range: their mean excretion was $24.8 \pm 3.2 \mathrm{TU} /$ day, a value that is significantly different from that of normal subjects $(P<0.001)$. Although 18 normal subjects who were depleted of sodium (9 meq $\mathrm{Na}$ diet for at least 5 days) increased their mean kallikrein excretion more than twofold, the patients with Bartter's syndrome still excreted significantly more kallikrein $(P<0.05)$.

Urinary kinin excretion (Fig. 2B). Mean urinary kinins of 25 normal subjects with daily dietary intakes of $109 \mathrm{meq} \mathrm{Na}$ and $100 \mathrm{meq} \mathrm{K}$ were $13.3 \pm 8.7 \mu \mathrm{g} / \mathrm{day}$ $($ mean $\pm 2 \mathrm{SD})$. These values are similar to those reported by Hial et al. (26) which were obtained by bioassay. Patients with Bartter's syndrome excreted significantly $(P<0.001)$ less kinins $(4.3 \pm 1.2 \mu \mathrm{g} / \mathrm{day})$, than the normal subjects on a 109-med sodium intake or those who were sodium depleted. The four patients with Bartter's syndrome with the lowest kinin excretion had higher PRA $(25.9 \pm 6.4$ vs. $5.9 \pm 0.4 \mathrm{ng} / \mathrm{ml}$ per h) higher urinary aldosterone excretion $(21.7 \pm 9.4$ vs. 7.9 $\pm 3.5 \mu \mathrm{g} /$ day $)$, higher kallikrein excretion $(28.7 \pm 9.4$ vs. $19.6 \pm 1.3 \mathrm{TU} / \mathrm{day}$ ), and lower creatinine clearances $\left(63 \pm 15\right.$ vs. $\left.113 \pm 13 \mathrm{~cm}^{3} / \mathrm{min}\right)$ than the three patients with the highest kinin excretion.

Plasma bradykinin (Fig. 2C). Mean plasma bradykinin for the 19 normal subjects on an intake of 109 meq $\mathrm{Na}$ and 100 meq $\mathrm{K}$ was $2.95 \pm 1.75 \mathrm{ng} / \mathrm{ml}$ $( \pm 2 \mathrm{SD})$. These values are similar to those reported by Talamo et al. (24). All patients but one with the syndrome had values above this range with a mean of $13.2 \pm 4.2 \mathrm{ng} / \mathrm{ml}(P<0.001)$. Although 14 sodiumdepleted normal subjects had a mean plasma bradykinin $(6.0 \pm 0.9 \mathrm{ng} / \mathrm{ml})$, which was significantly $(P$ $<0.05)$ higher than that in their sodiumn-replete state, it was still lower $(P<0.05)$ than the values in the patients with Bartter's syndrome.

Plasma prekallikrein. In 12 normal subjects plasma prekallikrein averaged $1.3 \pm 0.4 \mathrm{TU} / \mathrm{ml}($ mean $\pm 2 \mathrm{SD})$ on daily $\mathrm{Na}$ intakes of $109 \mathrm{mec} \mathrm{Na}$ and $100 \mathrm{meq} \mathrm{K} /$ day and $1.4 \pm 0.1$ on daily $\mathrm{Na}$ intakes of $9 \mathrm{met} / \mathrm{day}$. These values are similar to those reported by Imanari et al. (21) Basal plasma prekallikrein in four patients with Bartter's syndrome was $1.4 \pm 0.1 \mathrm{TU} / \mathrm{ml}$, and was not abnormal.

\section{Kallikrein-kinin system, prostaglandin synthetase inhibition}

The effects of prostaglandin synthetase inhibition on the urinary and plasma kallikrein-kinin system of each patient with Bartter's syndrome are plotted in Fig. 3 


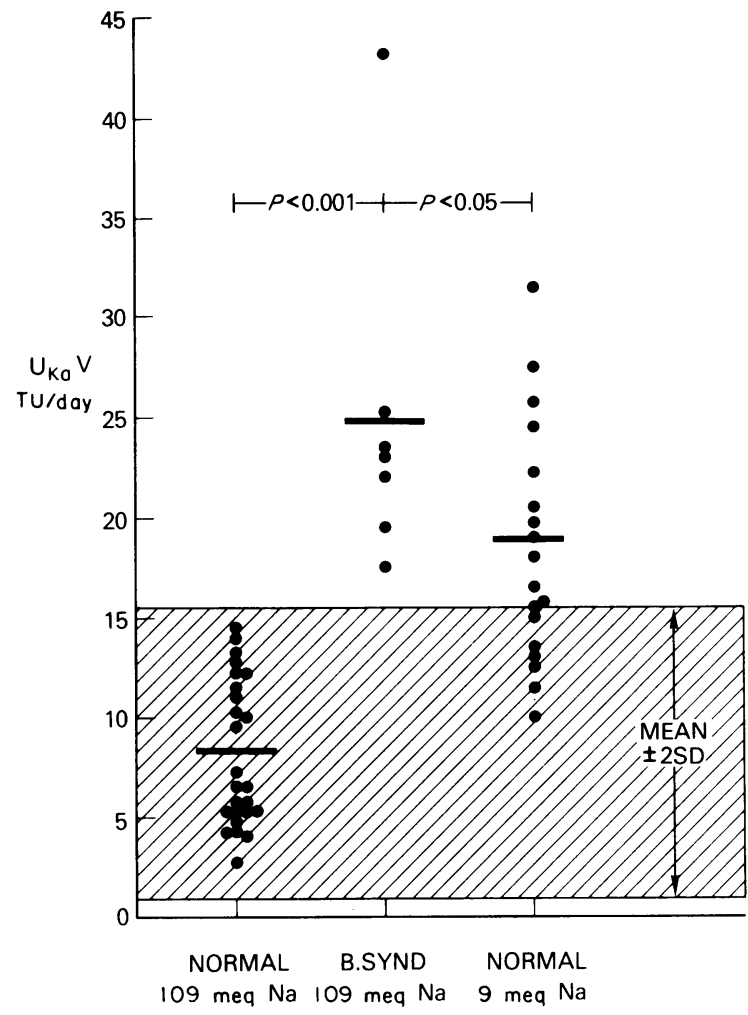

FIGURE 2A Urinary kallikrein $\left(\mathrm{U}_{\mathrm{Ka}} \mathrm{V}\right)$ in seven patients with Bartter's syndrome (B. Synd) in the basal state compared to that of normal subjects fed 109-meq and 9-meq/day sodium diets. The shaded area is the mean \pm 2 SD for normal subjects fed 109 meq sodium/day. Horizontal bars represent the mean for each group.

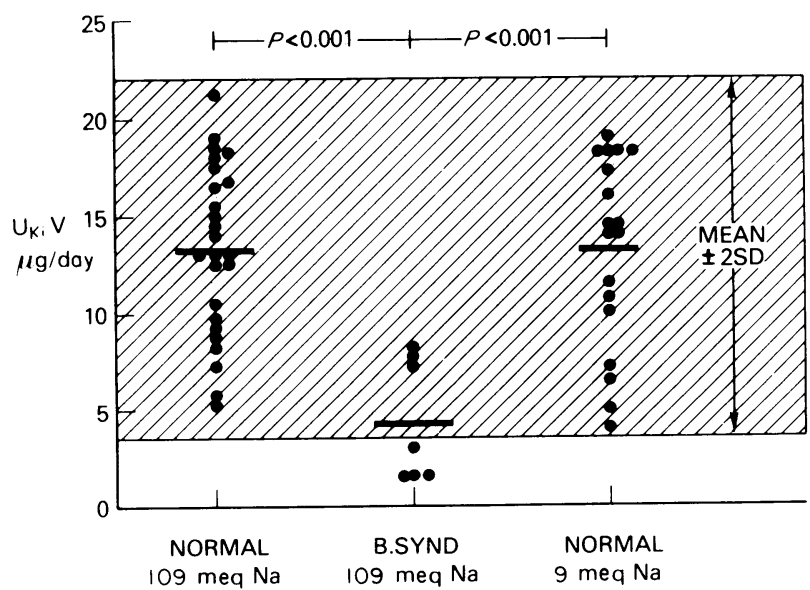

FIGURE 2B Urinary kinin excretion $\left(\mathrm{U}_{\mathbf{K i}} \mathrm{V}\right)$ in seven patients with Bartter's syndrome (B. Synd) in the basal state as compared to that of normal subjects fed 109-meq and 9-meq/ day sodium diets. The shaded area is the mean $\pm 2 \mathrm{SD}$ for normal subjects fed $109 \mathrm{meq}$ sodium/day. Horizontal bars represent the mean for each group. and the effects on daily mean kallikrein and kinin excretion are shown in Fig. 1. The effects of indomethacin on the kallikrein-kinin system of six sodiumdepleted normal subjects are presented in Table $I$.

Urinary kallikrein. Mean urinary kallikrein was significantly decreased by the 4 th day of prostaglandin synthetase inhibition in all seven patients with Bartter's syndrome, (Fig. 1) to a normal value of 12.4 $\pm 2.0 \mathrm{TU} /$ day on the 7 th day of treatment from a mean control value of $24.8 \pm 3.2 \mathrm{TU} /$ day (Fig. 3 ). When drug was withdrawn, urinary kallikrein remained significantly decreased after 3 days. In those patients who were followed for longer than 4 days, urinary kallikrein had returned to $88 \pm 3 \%$ of control excretion by the 7 th day. The daily changes in urinary kallikrein excretion closely paralleled the changes in aldosterone excretion rate (Fig. 1). Mean urinary kallikrein in normal subjects (Table I) was significantly lower during sodium depletion plus indomethacin than during sodium depletion alone.

Urinary kinin. Mean urinary kinins were significantly increased by prostaglandin synthetase inhibi-

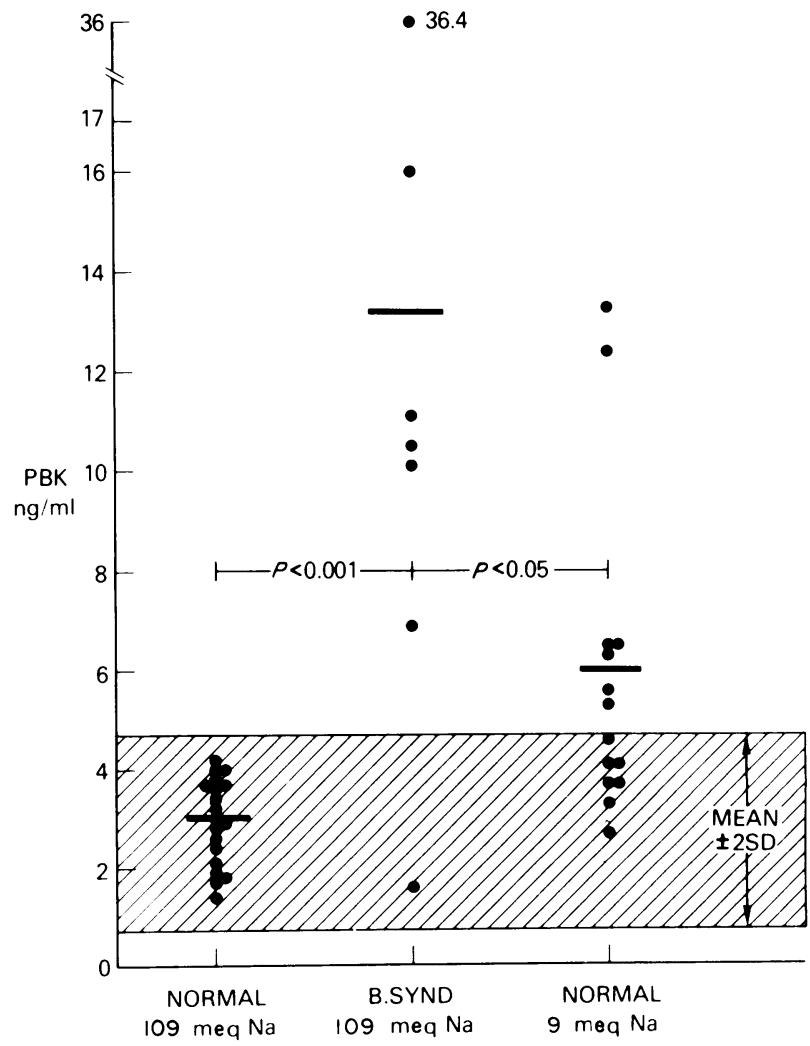

FIgure 2C Plasma bradykinin (PBK) (patients recumbent) in seven patients with Bartter's syndrome (B. Synd) in the basal state as compared to that of normal subjects fed 109-meq and 9-meq/day sodium diets. The shaded area is the mean \pm 2 SD for normal subjects fed $109 \mathrm{meq}$ sodium/day. Horizontal bars represent the mean for each group. 

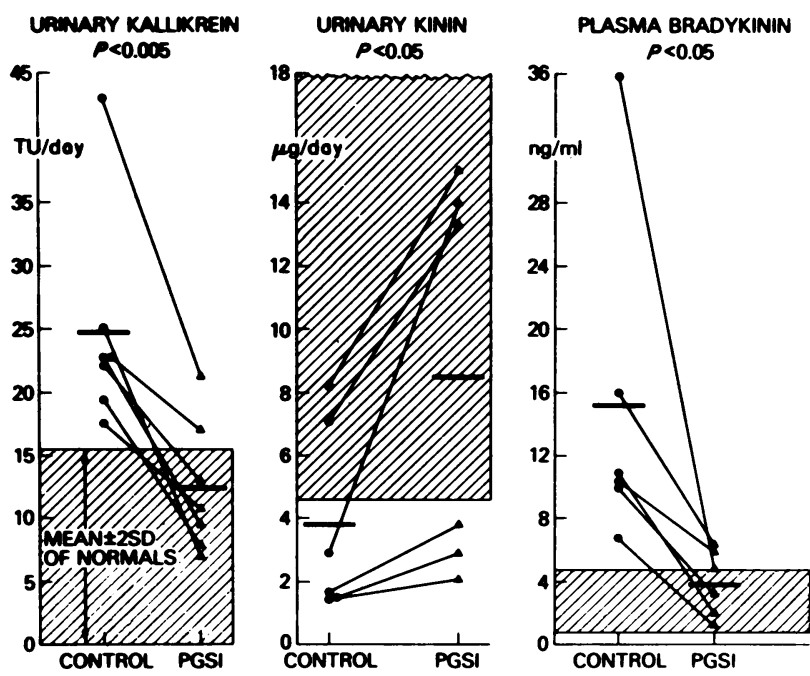

FIGURE 3 Effects of prostaglandin synthetase inhibition (PGSI) on urinary kallikrein excretion $\left(\mathrm{U}_{\mathrm{Ka}} \mathrm{V}\right)$ on the 7 th day of treatment in seven patients, on urinary kinin excretion $\left(\mathrm{U}_{\mathrm{Ki}} \mathrm{V}\right)$ on the 7th day of treatment in six patients, and on mean plasma bradykinin (PBK) on the 4th to 7 th days of treatment in six patients. The shaded area is the mean \pm 2 SD for normal subjects fed $109 \mathrm{meq} /$ day sodium. Horizontal bars represent the mean for each group.

tion in all six of the patients in whom they were measured, from control values of $3.8 \pm 1.3$ to $8.5 \pm 2.5$ $\mu \mathrm{g} /$ day (Fig. 3). The increase in urinary kinin excretion (Fig. 1) was rapid and maximal $(P<0.05)$ by the 3rd day. (It was elevated by $63 \pm 27 \%$ and $72 \pm 33 \%$ above control on the 1st and 2nd days, respectively, but the values were not statistically significant.) In response to prostaglandin inhibitors, those patients with the lower kinin excretion showed a greater decrease in UiPGEV ( $66 \pm 5 \%$ vs. $45 \pm 6 \%$ ), greater sodium retention on the lst day $(62 \pm 15$ meq compared to $37 \pm 15 \mathrm{meq})$, a greater weight gain by day $7(2.2 \pm 0.5$ $\mathrm{kg}$ compared to $0.8 \pm 0.2 \mathrm{~kg}$ ), greater potassium retention (98 \pm 46 meq vs. $73 \pm 11 \mathrm{meq})$, and a greater rise in serum potassium (1.1 meq/liter vs. $0.6 \mathrm{meq} / \mathrm{liter})$. Thus, not only did the patients who excreted the least kinins have the greater basal hormonal derangements, but they also showed a greater response to prostaglandin inhibitors. When treatment was stopped, urinary kinin excretion fell rapidly to control values by the 1st day, and remained unchanged for the remainder of the period. In the normal subjects indomethacin (Table I) did not significantly affect mean kinin excretion.

Plasma bradykinin (Fig. 3). Mean plasma bradykinin during the latter part of prostaglandin synthetase inhibition (days 4-7) was markedly reduced from a control value of $15.2 \pm 4.4 \mathrm{ng} / \mathrm{ml}$ to a normal value of $3.9 \pm 0.9 \mathrm{ng} / \mathrm{ml}(P<0.05)$ in the six patients with Bartter's syndrome in whom it was measured. Mean plasma bradykinin in recumbent or upright normal subjects was not significantly affected by treatment with indomethacin.

Plasma prekallikrein. Mean plasma prekallikrein was $1.4 \pm 0.2 \mathrm{TU} / \mathrm{ml}$ in the latter half of treatment and thus not different from the control value of $1.4 \pm 0.1$ $\mathrm{TU} / \mathrm{ml}$

\section{DISCUSSION}

In this study, PRA and bradykinin and urinary kallikrein, aldosterone, and immunoreactive prostaglandin E were elevated in patients with Bartter's syndrome. Despite increased excretion of kallikrein, urinary kinin was subnormal. Inhibition of prostaglandin synthesis restored to normal PRA, plasma bradykinin, urinary kallikrein, kinin, aldosterone, and UiPGEV. The rise in kinin excretion occurred despite a decrease in kallikrein excretion. Prostaglandin inhibition also decreased creatinine clearance, produced sodium and potassium retention and weight gain, and partially corrected the hypokalemic alkalosis that characterizes the syndrome. Prostaglandin inhibition in sodium-depleted normal man decreased UiPGEV, PRA, aldosterone, and urinary kallikrein but did not affect plasma or urinary kinins, sodium excretion, creatinine clearances, or serum potassium.

Bradykinin, a potent vasodilator peptide, is generated by a limited proteolytic system analogous to the renin-angiotensin system (29). The proteolytic enzyme, kallikrein, generates bradykinin from precursor proteins, kininogens; it thus resembles renin, which generates angiotensin I from angiotensinogen. Whereas the potent vasodilatory effects of kinins are partly mediated by prostaglandins (30-32) (bradykinin stimulates synthesis of prostaglandins and bradykinininduced vasodilatation is attenuated by prostaglandin synthetase inhibition) the vasoconstrictor effects of angiotensin II are attenuated by prostaglandins (32, 33). Current concepts regarding the interplay of these vasoactive systems suggest that the interaction of bradykinin and the prostaglandins may modulate the vasoconstrictor effects of angiotensin II. That the kallikrein-kinin system exists in glands (e.g., exocrine glands and kidneys), and plasma as separate systems, is supported by the following evidence. ( $a$ ) Glandular kallikrein is not normally found in plasma (29). (b) Enzyme kinetic studies of human plasma prekallikrein show that high molecular weight kininogen (mol wt $=200,000)$ is hydrolyzed much more rapidly than low molecular weight kininogen $(\mathrm{mol} \mathrm{wt}=50,000)$, whereas both substrates are hydrolyzed equally well by human urinary kallikrein (34). (c) Plasma kallikrein generates bradykinin directly, but urinary and glandular kallikreins generate lysyl-bradykinin, which is then converted to bradykinin by an amino- 
peptidase (35). (d) Urinary kallikrein is synthesized by the kidney (13), is located on the luminal surface of distal tubular cells $(36,37)$, and is released into urine (13). Bradykinin infused into a renal artery is hydrolyzed by proximal tubule cells and is poorly recovered in urine (38), and this suggests that urinary kinins probably originate in the distal tubule fluid and not from filtered plasma bradykinin $(38,39)$. If urinary kinins do originate in the distal tubule as the above evidence suggests, this would argue against degradation by kininases or net reabsorption of kinins in distal tubular fluid (39). Unlike that in blood, kininase activity in human urine is low; only $50 \%$ of $\left[{ }^{3} \mathrm{H}\right]$ bradykinin incubated in human urine at $37^{\circ} \mathrm{C}$ is destroyed in $8 \mathrm{~h}$ (unpublished observation). Thus, it is likely that when samples are properly collected and assayed, the measurement of urinary kinins represents the net excretion of mostly unmetabolized bradykinin and lysyl-bradykinin that are generated in the distal tubule. Although kallikrein has been localized in the renal tubule, the mechanisms which make substrate available to kallikrein in the distal tubule and those factors which may alter the fate of kinins generated in the distal tubule are unknown.

The high levels of plasma bradykinin observed in Bartter's syndrome may partly account for the resistance to the pressor action of angiotensin II and the persistence of normal blood pressure in these severely hyperreninemic patients. When the patients with Bartter's syndrome were treated with prostaglandin synthetase inhibitors, their renin activity was markedly suppressed but their blood pressure did not change. This paradox may be explained by the decrease of plasma renin and plasma bradykinin pari passu during prostaglandin inhibition, so that pressor and depressor effects were diminished simultaneously.

The mechanism by which basal plasma bradykinin is elevated and then altered by prostaglandin inhibitors in Bartter's syndrome is not known. Although other studies have indicated a parallelism between changes of plasma bradykinin and those of plasma angiotensin II or renin activity in response to changes of posture, salt depletion, or saline infusion in normal subjects $(12,17)$, in the present study, treatment of normal subjects with indomethacin decreased PRA but did not affect plasma bradykinin (Table I). This difference in the response of plasma bradykinin in normal subjects and in patients with Bartter's syndrome may be attributed to the much higher basal values of plasma bradykinin and PRA in the patients with Bartter's syndrome (Fig. 1, Table I). Alternatively, this difference may be attributed to the marked antinatriuresis, antikaliuresis, and expansion of the extracellular fluid volume caused by indomethacin in patients with the syndrome but not in the normals. Nevertheless, available data suggests that the basal levels of plasma bradykinin in patients with Bartter's syndrome were not elevated by increased kinin generation from plasma kininogen by plasma kallikrein as plasma prekallikrein was normal and in two of the patients, so was plasma kininogen. Alternatively, bradykinin may be high because of decreased destruction. Angiotensin converting enzyme, present in the lung and other tissues, inactivates bradykinin (40), and this action is inhibited in vitro by several peptides, including angiotensin I, angiotensin II, and the dipeptide product of angiotensin I hydrolysis, histidyl-leucine (41). Although it is tempting to postulate that total bradykinin hydrolysis may be significantly inhibited in vivo by the high levels of angiotensin I and II found in this syndrome, there is no evidence that this occurs. In fact, this hypothesis ignores the contribution made by other kininases (42) which are more important in the destruction of plasma bradykinin (43). Indeed, in 10 hypertensive patients with unequivocal biochemical evidence of converting enzyme inhibition with SQ20881, plasma bradykinin was not changed (44). Thus, it appears unlikely that the high levels of bradykinin result from inhibition of converting enzyme by elevated endogenous levels of angiotensin I. Whatever the mechanism for the increased bradykinin it is likely that it modulates the pressor activity of angiotensin II in this syndrome.

Urinary kallikrein excretion is increased in conditions in which sodium-retaining steroids are present in excess (14-17). Consistent with this observation are the report by Lechi et al. (45) and our present findings that patients with Bartter's syndrome excrete more kallikrein than normal subjects. Indeed, patients with Bartter's syndrome excreted three times as much kallikrein as sodium-replete normal subjects, but only one-third more than sodium-depleted normal subjects. When renal prostaglandin synthesis was inhibited in patients with this syndrome, urinary kallikrein decreased slowly and simultaneously with the fall in aldosterone excretion (Fig. 1). When prostaglandin synthetase inhibitor was stopped, urinary kallikrein was slower to return to control than aldosterone. In those subjects followed for longer periods, kallikrein excretion returned to control values. (It has been our experience that kallikrein often lags behind changes in aldosterone by as much as $2-3$ days.) In normal subjects, both kallikrein and aldosterone excretion were lower during indomethacin. These data further support the observation, as yet unexplained, that production of urinary kallikrein depends, in part, upon the action of aldosterone.

To our knowledge, an abnormality in urinary kinins has not been reported. In patients with Bartter's syndrome, urinary kinins are not only abnormal, but also 
appear to reflect the severity of hormonal derangements and the response to prostaglandin inhibitors. The finding in this syndrome of values for urinary kinin one-third that of normal despite a very high urinary kallikrein is unexpected. This inverse relationship between urinary kallikrein and kinins was persistent: during prostaglandin synthetase inhibition kinin excretion rose abruptly as urinary kallikrein fell, and when treatment was stopped kinin excretion fell rapidly as urinary kallikrein slowly returned to control values. This inverse relationship between kallikrein and kinin suggests that other factors such as prostaglandins or prostaglandin-dependent renal changes control kinin excretion in this syndrome.

Patients with persistent psychogenic vomiting, hypokalemic alkalosis, hyperreninemia and vascular hyposensitivity to angiotensin II show excessive production of prostaglandin $\mathrm{E}_{2}\left(\mathrm{PGE}_{2}\right)(46)$ and low urinary kinins (unpublished observations). It is possible that hypokalemia per se and its associated renovascular and hormonal changes (47), which are partly prostaglandin-dependent (47), accounted for the subnormal kinin excretion in this syndrome. It is unlikely, however that prostaglandins per se mediated the observed changes in kinin excretion in Bartter's syndrome as prostaglandin inhibition in normal subjects had no effect on kinin excretion, but they may have done so via changes in delivery of kininogen to the distal tubule where kallikrein is located, or in destruction by kininases or in the reabsorption of kinins.

Prostaglandin synthetase inhibition in these seven patients with Bartter's syndrome resulted in mean hormonal and metabolic changes that were similar to those in the four patients reported previously (5). The abrupt decrease in iPGEV on the 1st day of treatment was associated with a decrease in creatinine clearance, retention of sodium, and gain in body weight. None of these changes were observed in normal subjects. As blood pressure did not change, renal vasoconstriction, which has been suggested to explain the decrease in renal blood flow observed to occur in response to inhibition of prostaglandin synthetase (48), probably explains the decrease in creatinine clearance in patients with this syndrome. Such changes in renal hemodynamics, may have increased the proximal tubular reabsorption of sodium $(49,50)$. The recent demonstration of $\mathrm{PGE}_{2}$ inhibits the transport of sodium in the collecting tubule of the rabbit (51) suggests that, if such an action exists in patients with Bartter's syndrome an increase in distal tubule reabsorption of sodium may also have contributed to the decrease in sodium excretion associated with prostaglandin inhibition. Whereas the data do not allow an assessment of the roles of proximal and distal tubular reabsorption of sodium in the retention of sodium, the observation that the excretion of potassium closely paralleled that of sodium (Fig. 1) could be explained as a result of changes in flow of tubular fluid past the potassium secretory site (52) produced by changes in glomerular filtration, proximal tubular reabsorption, or both.

The period of escape from the significant antinatriuretic and antikaliuretic effects of prostaglandin inhibition occurred after only 2 days of treatment. One determinant of this phenomenon may have been marked expansion of extracellular fluid which may have led to a decrease in proximal tubular reabsorption of sodium (53). Another factor may have been the coincident increase in urinary kinins which occurred on the 3rd day of treatment. If kinins contributed to the escape from the antinatriuretic effects of prostaglandin inhibition, it is possible that they did so by inhibition of sodium reabsorption. Somewhat against the notion that this might occur in the distal tubule is the observation that distal fractional sodium chloride reabsorption during water diuresis in patients with Bartter's syndrome was not changed by treatment with indomethacin (46).

Finally, the information presented can be used to address the possible pathophysiologic mechanisms of Bartter's syndrome. Although many of the hormonal abnormalities in Bartter's syndrome are directionally similar to those observed in sodium-depleted normals, it is unlikely that volume depletion is a major factor in the pathogenesis of this disorder because marked expansion of the extracellular fluid volume with saline or albumin does not correct the hormonal or metabolic derangements. Also, patients with Bartter's syndrome can conserve sodium normally in response to a low sodium intake but do continue to lose potassium (3). Whereas treatment of this disorder with prostaglandin inhibitors dramatically improved the hormonal and metabolic abnormalities it failed to fully correct the hypokalemia. Indeed, long-term treatment with these inhibitors does not completely correct the renal loss of potassium or hypokalemia, even when it restores plasma renin, aldosterone, and UiPGEV to normal (54). These findings suggest that hypokalemia may cause rather than be caused by hyperreninemia and aldosteronism. In keeping with this formulation is the observation that bilateral adrenalectomy does not correct the hypokalemia in patients with Bartter's syndrome $(55,56)$. Furthermore, hypokalemia in dogs caused increased excretion of prostaglandin E, elevated PRA, and hyposensitivity to angiotensin II infusions; indomethacin restored these abnormalities toward normal (47). In addition, as mentioned previously, patients with persistent psychogenic vomiting, who were hypokalemic also showed increased excretion of $\mathrm{PGE}_{2}$, hyper- 
reninemia, aldosteronism, low urinary kinins, and hyposensitivity to angiotensin II. Thus, the increased synthesis of prostaglandins in Bartter's syndrome is probably not the primary abnormality but secondary to hypokalemia.

Whereas hypokalemia is probably the most proximal abnormality in the pathogenesis of Bartter's syndrome, it is unlikely that it results from renal loss per se for two reasons: $(a)$ primary potassium deficiency tends to cause sodium retention (57), which does not occur in Bartter's syndrome, and $(b)$ it is difficult to conceive of a mechanism which would allow the kidney to excrete inappropriately large quantities of potassium without an increase in distal tubular flow (52) as may occur with an inappropriately low fractional reabsorption of sodium chloride in the proximal tubule, in the loop of Henle, or in both. Thus, the findings in Bartter's syndrome are most consistent with a defect in the tubular reabsorption of sodium chloride as the most proximal cause of the syndrome. Indeed, recent evidence, based on free water clearance studies (46), suggests the presence of a defect in chloride reabsorption in the ascending loop of Henle. This defect may promote potassium loss by enhancing distal tubular flow which increases potassium exchange and loss $(46,52,58)$.

Addendum. While this manuscript was being reviewed the following articles appeared on this subject $(59,60)$.

\section{ACKNOWLEDGMENTS}

The authors gratefully acknowledge the expert technical assistance of Messers David Telles, Edward Nemore, and Henry Porter, the fine secretarial work of Mrs. Peggy Davis, and express their sincere gratitude to Dr. Jack V. Pierce for his generous support of the clinical investigation of the kallikrein-kinin system.

\section{REFERENCES}

1. Bartter, F. C., P. Pronove, J. R. Gill, Jr., and R. C. McCardle. 1962. Hyperplasia of the juxtaglomerular complex with hyperaldosteronism and hypokalemic alkalosis. Am. J. Med. 33: 811-828.

2. Gill, J. R., Jr., and F. C. Bartter. 1964. Hyperplasia of the juxtaglomerular complex with hyperaldosteronism and hypokalemic alkalosis. In Water and Electrolyte Metabolism III. J. de Graeff and B. Leijnse, editors. Elsevier Scientific Publishing Co., Amsterdam. 119-124.

3. Bravo, E., and F. C. Bartter. 1968. The syndrome of juxtaglomerular hyperplasia and hyperaldosteronism without hypertension; studies on pathophysiological mechanism. Clin. Res. 16: 263.

4. Verberckmoes, R., B. van Domme, J. Clement, A. Amery, and P. Michielsen. 1976. Bartter's syndrome with hyperplasia of renomedullary cells: successful treatment with indomethacin. Kidney Int. 9: 302-307.

5. Gill, J. R., Jr., J. C. Frolich, R. E. Bowden, A. A. Taylor, H. R. Keiser, H. W. Seyberth, J. A. Oates, and F. C.
Bartter. 1976. Bartter's syndrome: A disorder characterized by high urinary prostaglandins and a dependence of hyperreninemia on prostaglandin synthesis. Am. J. Med. 61: 43-51.

6. Fichman, M., N. Telfer, P. Zia, P. Speckart, M. Golub, and R. Rude. 1976. Role of prostaglandins in the pathogenesis of Bartter's syndrome. Am. J. Med. 60: 785-797.

7. Norby, L., W. Flamenbaum, R. Lentz, and P. Ramwell. 1976. Prostaglandins and aspirin therapy in Bartter's syndrome. Lancet. II: 604-606.

8. McGiff, J. C., N. A. Terragno, K. U. Malik, and A. J. Lonigro. 1972. Release of a prostaglandin E-like substance from canine kidney by bradykinin. Circ. Res. 31: $36-43$.

9. McGiff, J. C., H. D. Itskovitz, A. Terragno, and P. Y-K. Wong. 1976. Modulation and mediation of the action of the renal kallikrein-kinin system by prostaglandins. Fed. Proc. 35: 175-180.

10. Nasjletti, A., and J. Colina-Chourio. 1976. Interaction of mineralocorticoid, renal prostaglandins and the renal kallikrein-kinin system. Fed. Proc. 35: 189-193.

11. Zusman, R. M., and H. R. Keiser. 1977. Prostaglandin $\mathrm{E}_{2}$ biosynthesis by rabbit renomedullary interstitial cells in tissue culture: Mechanism of stimulation by angiotensin II, bradykinin and arginine vasopressin. J. Biol. Chem. 252: 2069-2071.

12. Wong, P. Y., R. C. Talamo, G. H. Williams, and R. W. Coleman. 1975. Response of the kallikrein-kinin and renin-angiotensin systems to saline infusion and upright posture. J. Clin. Incest. 55: 691-698.

13. Nustad, K.. K. Vaaje, and J. V. Pierce. 1975. Synthesis of kallikreins by rat kidney slices. Br. J. Pharmacol. 53: $229-234$.

14. Margolius, H. S., D. Horwitz, R. G. Geller, R. W. Alexander, J. R. Gill, Jr., J. J. Pisano, and H. R. Keiser. 1974. Urinary kallikrein excretion in normal man. Relationships to sodium intake and sodium-retaining steroids. Circ. Res. 35: 812-819.

15. Margolius, H. S., D. Horwitz, J. J. Pisano, and H. R. Keiser. 1976. Relationships among urinary kallikrein, mineralocorticoids and human hypertensive disease. Fe'd. Proc. 35: 203-206.

16. Margolius, H. S., D. Horwitz, J. J. Pisano, and H. R. Keiser. 1974. Urinary kallikrein excretion in hypertensive man. Relationships to sodium intake and sodiumretaining steroids. Circ. Res. 35: 820-825.

17. Vinci, J. M., R. M. Zusman, R. E. Bowden, D. Horwitz, and H. R. Keiser. 1977. Relationship of urinary and plasma kinins to sodium retaining steroids and plasma renin activity. Clin. Res. 25: 450A. (Abstr.)

18. Williams, G. C., D. S. Young, M. R. Stein, and E. Cotlove. 1970. Biological and analytic components of variation in long term studies of serum constituents in normal subjects. Clin. Chem. 16: 1016-1021.

19. Menard, J., and K. J. Catt. 1972. Measurement of renin activity, concentration and substrate in rat plasma by radioimmunoassay of angiotensin I. Endocrinology. 90: $422-430$.

20. Sealev, J. E., F. R. Buhler, J. H. Laragh, E. L. Manning, and H. R. Brumner. 1972. Aldosterone excretion. Physiological variations in man measured by radioimmunoassay or double isotope dilution. Circ. Res. 31: 367-378.

21. Imanari, T., T. Kaizu, H. Yoshida, K. Yates, J. V. Pierce, and J. J. Pisano. 1976. Radiochemical assays for human urinary, salivary and plasma kallikrein. In Chemistry and Biology of the Kallikrein-Kinin System in Health and Disease. J. J. Pisano and K. F. Austen, editors. 
Fogarty International Center Proceedings. U. S. Government Printing Office, Washington, D. C. No. 27. 205-213.

22. Beaven, V. H., J. V. Pierce, and J. J. Pisano. 1971. Sensitive isotopic procedure for the assay of esterase activity: Measurement of human urinary kallikrein. Clin. Chim. Acta. 32: 67-73.

23. Pierce, J. V. 1970. Purification of mammalian kallikreins, kininogens and kinins. In Handbook of Experimental Pharmacology: Bradykinin, Kallidin, and Kallikrein. E. G. Erdos, editor. Springer-Verlag KG, Berlin. 25: $21-51$.

24. Talamo, R. C., E. Haber, and K. F. Austen. 1969. A radioimmunoassay for bradykinin in plasma and synovial fluid. J. Lab. Clin. Med. 74: 816-827.

25. Wintroub, B. A., J. Spragg, D. J. Stechschulte, and K. F. Austen. 1973. Characterization and immunoassays for components of the kinin-generating system. In Mechanisms in Allergy: Reagin-Mediated Hypersensitivity. T. L. Goodfriend, A. Sehan, and R. Orange. Marcel Dekker, Inc., New York. 495-512.

26. Hial, V., H. R. Keiser, and J. J. Pisano. 1976. Origin and content of methionyl-lysyl-bradykinin, lysyl-bradykinin and bradykinin in human urine. Biochem. Pharmacol. 25: 2499-2503.

27. Pierce, J. V., and M. E. Webster. 1966. The purification and some properties of two different kallidinogens. In Hypotensive Peptides. E. G. Erdos, N. Back, and F. Sicuteri, editors. Springer-Verlag New York, Inc., New York. 130-138.

28. Rodbard, D., and G. R. Frazier. 1973. Radioimmunoassay data processing. In National Technical Information Service, Springfield, Va. 2nd edition. USA 2215l, Reports no. PB 217366 and PB 217367.

29. Pisano, J. J. 1975. Chemistry and biology of the kallikrein-kinin system. In Proteases and Biological Control. Cold Spring Harbor Laboratory, Cold Spring Harbor, N. Y. 199-222.

30. Terragno, D. A., K. Crowshaw, N. A. Terragno, and J. C. McGiff. 1975. Prostaglandin synthesis by bovine mesenteric arteries and veins. Circ. Res. 37(Suppl I): 76-80.

31. Messina, E. J., R. Weiner, and G. Kaley. 1975. Inhibition of bradykinin vasodilation and potentiation of norepinephrine and angiotensin vasoconstriction by inhibitors of prostaglandin synthesis in skeletal muscle of the rat. Circ. Res. 37: 430-437.

32. Needleman, P., G. R. Marshall, and B. E. Sobel. 1975. Hormone interactions in the isolated rabbit heart: Synthesis and coronary vasomotor effects of prostaglandin, angiotensin, and bradykinin. Circ. Res. 37: 802-808.

33. Aiken, J. W., and J. R. Vane. 1973. Intrarenal prostaglandin release attenuates the renal vasoconstrictor activity of angiotensin. J. Pharmacol. Exp. Ther. 184: $678-687$.

34. Jacobsen, S. 1966. Substrates for plasma kinin-forming enzymes in dog, and rabbit plasmas. $\mathrm{Br}$. J. Pharmacol. 26: 403-411.

35. Pierce, J. V., and M. E. Webster. 1961. Human plasma kallidins: Isolation and chemical studies. Biochem. Biophys. Res. Commun. 5: 353-357.

36. Orstavik, T. B., K. Nustad, P. Brandtzaeg, and J. V. Pierce. 1976. Cellular origin of urinary kallikrein. J. Histochem. Cytochem. 24: 1037-1039.

37. Carretero, O. A., and A. G. Scicli. 1976. Renal kallikrein: Its localization and possible role in renal function. Fed. Proc. 35: 194-198.

38. Nasjletti, A., J. Colina-Chourio, and J. C. McGiff. 1975.
Disappearance of bradykinin in the renal circulation of dogs. Circ. Res. 37: 59-65.

39. Oparil, S., F. A. Carone, T. N. Pullman, and S. Nakamura. 1976. Inhibition of proximal tubular hydrolysis and reabsorption of bradykinin by peptides. Am. J. Physiol. 231: 743-748.

40. Dorer, F. E., J. R. Kahn, K. E. Lentz, M. Levine, and L. T. Skeggs. 1974. Hydrolysis of bradykinin by angiotensinconverting enzyme. Circ. Res. 34: 824-827.

41. Alabaster, V. A., and Y. S. Bakhle. 1973. The bradykininase activities of extracts of dog lung. Br. J. Pharmacol. 47: 799-807.

42. Erdos, E. G. 1971. Enzymes that inactivate vasoactive peptides. In Handbook of Experimental Pharmacology: Springer-Verlag KG, Berlin. 28(Part 2): 620-653.

43. Talamo, R. C. 1976. Kinetics of kinin release and disappearance. In Chemistry and Biology of the KallikreinKinin System in Health and Disease. J. J. Pisano and K. F. Austen, editors. Fogarty International Center Proceedings. U. S. Government Printing Office, Washington, D. C. No. 27. 307-312.

44. Vinci, J. M., D. Horwitz, R.M. Zusman, K. Catt, and H. R. Keiser. 1977. The effect of angiotensin converting enzyme inhibition on angiotensin II, bradykinin and prostaglandin E in hypertensive man. Circ. Suppl. 56: III -214 .

45. Lechi, A., G. Covi, C. Lechi, F. Mantero, and L. A. Scuro. 1976. Urinary kallikrein excretion in Bartter's syndrome. J. Clin. Endocrinol. Metab. 43: 1175-1178.

46. Gill, J. R., Jr., F. C. Bartter, A. A. Taylor, and N. Radfar. 1976. Impaired tubular chloride reabsorption as a proximal cause of Bartter's Syndrome. Clin. Res. 25: 526A. (Abstr.)

47. Galvez, O. G., W. H. Bay, B. W. Roberts, and T. F. Ferris. 1977. The hemodynamic effects of potassium deficiency in the dog. Circ. Res. 40(Suppl. 1): I 11-16.

48. Kimberly, R. P., J. R. Gill, Jr., R. E. Bowden, and P. H. Plotz. 1977. Effects of aspirin on renal blood flow, glomerular filtration rate, and renal prostaglandins in SLE. Arthritis Rheum. 20: 123.

49. Martino, J. H., and L. E. Earley. 1967. Demonstration of a role of physical factors as determinants of the natriuretic response to volume expansion. J. Clin. Invest. 46: 1963-1978.

50. Brenner, B. M., and J. L. Troy. 1971. Postglomerular vascular protein concentration: Evidence for a causal role in governing fluid reabsorption and glomerulotubular balance by the renal proximal tubule. J. Clin. Invest. 50: 336-349.

51. Stokes, J. B., and J. P. Kokko. 1977. Inhibition of sodium transport by prostaglandin E. across the isolated, perfused rabbit collecting tubule. J. Clin. Invest. 59: 10991104

52. Khuri, R. N., M. Wiederholt, N. Striedor, and G. Giebisch. 1975. Effects of flow rate and potassium intake on distal tubular potassium transfer. Am. J. Physiol. 228: $1249-1261$.

53. Rector, F. C., Jr., G. Van Giesen, F. Kiil, and D. W. Seldin. 1964. Influence of expansion of extracellular volume on tubular reabsorption of sodium independent of changes in glomerular filtration rate and aldosterone activity. J. Clin. Invest. 43: 341-348.

54. Bowden, R. E., J. R. Gíll, Jr., N. Radfar, A. A. Taylor, and H. R. Keiser. 1978. Prostaglandin synthetase inhibitors in Bartter's syndrome-Effect on immunoreactive prostaglandin E excretion.JAMA (J.Am. Med.Assoc.). 239: $117-121$. 
55. Trygstad, C. W., J. A. Mangos, J. M. B. Bloodworth, Jr., and C. C. Lobeck. 1969. A sibship with Bartter's syndrome: Failure of total adrenalectomy to correct the potassium wasting. Pediatrics. 44: 234-242.

56. Takaysee, H. Y., Y. Aso, and K. Lakanchi. 1971. A case of Bartter's syndrome with surgical treatment followed for four years. J. Clin. Endocrinol. Metab. 32: 842-849.

57. Black, D. A. K., and M. D. Milne. 1952. Experimental potassium depletion in man. Clin. Sci. (Oxf.). 11: $397-415$.
58. Malnic, G., R. M. Klose, and G. Giebisch. 1964. Micropuncture study of renal potassium excretion in the rat. Am. J. Physiol. 206: 674-686.

59. Halushka, P. V., H. Wohltmann, P. J. Privitera, G. Hurwitz, and H. S. Margolius. 1977. Bartter's syndrome: Urinary prostaglandin E-like material and kallikrein: Indomethacin effects. Ann. Intern. Med. 87: 281-286.

60. McGiff, J. C. 1977. Bartter's syndrome results from an imbalance of vasoactive hormones. Ann. Intern. Med. 87: 369-372. 